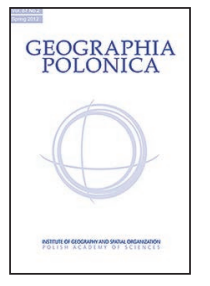

\title{
LICHENOMETRIC CURVE FOR THE SOUTHERN SLOPE OF THE TATRA MOUNTAINS (SLOVAK TATRAS)
}

\author{
Stanisław Kędzia ${ }^{1}$ (D) • Juraj Hreško² (D) - Gabriel Bugár ${ }^{2}$ (D) \\ ${ }^{1}$ Institute of Geography and Spatial Organization \\ Polish Academy of Sciences \\ Jana 22, 31-018 Kraków: Poland \\ e-mail: kedzia@zg.pan.krakow.pl (corresponding author) \\ ${ }^{2}$ Department of Ecology and Environmental Sciences, Faculty of Natural Sciences \\ Constantine The Philosopher University in Nitra \\ Trieda Andreja Hlinku 1, 94974 Nitra: Slovakia \\ e-mail: jhresko@ukf.sk・gbugar@ukf.sk
}

\begin{abstract}
This paper presents the first lichenometric curve of Rhizocarpon geographicum for the southern slope of the Tatra Mts (Slovak Tatras). The curve was developed based on measurements carried out in the years 20182019. The curve was constructed using measurement results from 9 objects of known time of origin, situated in the Tatra Mts. at an altitude of 1,250-1,900 m a.s.l. On each of them, the diameter of the 5 largest thalli was measured. Their average diameter was assigned an age value and then the lichen factor was calculated and a classical lichenometric curve was developed, as well as a modified curve taking into account the effect of altitude on the rate of thallus growth. The lichen factor is in the range between approx. $34.5 \mathrm{~mm} / 100$ years at $1,900 \mathrm{~m}$ a.s.l. and $44 \mathrm{~mm} / 100$ years at $1,250 \mathrm{~m}$ a.s.l. No significant differences were found in the rate of thallus growth between the southern and northern slopes of the Tatra Mts.
\end{abstract}

\section{Key words}

lichenometric dating • Rhizocarpon geographicum • Tatra Mountains

\section{Introduction}

Since the time when the work by R.E. Beschel (1950), presenting the basics of the lichenometric dating method, appeared in the literature in the 1950s, many publications in this field have been published, which have made the principles of using this method more detailed and increased the accuracy of dating (Beschel, 1961, 1973; Jochimsen, 1973; Armstrong, 1976, 1978, 1981, 1983, 2002, 2006, 2013, 2015, 2016; Lock, Andrews, \& Webber, 1979; Innes, 1982, 1983, 1984, 1985a,b, 1988; Coxson \& Kershaw, 1983; Benedict, 1990, 1991, 2008, 2009; Karlèn \& Black, 2002; Armstrong \& Bradwell, 2001, 
2010a,b, 2015; Bradwell, 2004; Trenbirth \& Matthews, 2010). They have demonstrated, among other things, that an essential precondition for the accuracy of dating by this method is a properly constructed lichenometric curve (Kędzia, 2015). Moreover, it has been proven that the lichenometric curve for a specific mountain area varies depending on the altitudinal zones or with respect to the individual parts of the area (e.g. Beschel, 1961; Kotarba, 1988; Armstrong, 2016). Due to the low cost intensity and simplicity of the method, lichenometric dating is used in various sciences; it is particularly common in geomorphology (Denton \& Karlén, 1973; Karlén, 1973; Webber \& Andrews, 1973, Matthews, 1974; Birkenmajer, 1981, 1982, 1991; Innes, 1983, 1984, 1988; 1985b; Kotarba, 1988, 1989, 1991, 2001; Dąski, 2002, 2007; Bradwell, 2009; Armstrong \& Bradwell, 2010a; Sołomina, Ivanov, \& Bradwell, 2010).

Although more than half a century has passed since the first applications of this method, it is often disregard. The reason for this is mainly the difficulty in developing a lichenometric curve for a particular area. It is not always possible to find a sufficient number of objects that would meet the requirements of this dating method and thus guarantee its accuracy. Typically, it proves impossible to meet the basic criteria for such objects, i.e. known date of their formation, the presence of thalli with undisturbed growth (e.g. by high vegetation or roofing) and an appropriately large number of objects having these features in a certain range of altitudes (applies to mountains). It is not uncommon that, only two or three out of 50 pre-selected objects meet all the requirements of this dating method.

In the Tatra Mts., the first growth curve of Rhizocarpon geographicum thalli for their northern slope was developed by A. Kotarba over 30 years ago (Kotarba, 1988). The lichen factor (thallus growth in $\mathrm{mm}$ in the first 100 years) determined at that time was $32.5 \mathrm{~mm}$ for the temperate cold zone $(1,850$ $2,200 \mathrm{~m}$ a.s.l.) and $38.1 \mathrm{~mm}$ for the very cool zone (1,550-1,850 $\mathrm{m}$ a.s.l.). In the following years, based on the factors determined, the first lichenometric dating of the debris slopes in the Sucha Woda Valley was carried out (Kotarba, 1989, 1991, 1992, 1997, 2001, 2004; Jonasson, Kot, \& Kotarba, 1991; Kotarba \& Pech, 2002). Since then, this dating method has been used in many studies in the field of geomorphology and cryosphere research (Kędzia, 2010, 2011, 2013a, b, 2014, 2015a,b; Gądek, Grabiec, Kędzia, \& Raczkowska, 2016). All these works concerned exclusively the northern slope of the Tatra Mts., i.e. mostly the Polish part of these mountains. Due to the climatic differences between the northern and southern parts of the Tatra Mts., mainly with respect to the distribution of temperature and precipitation (Hess, 1965, 1974; Ustrnul, Walawender, Czekierda, Štastný, Lapin, \& Mikulová, 2015), the lichenometric curve developed by A. Kotarba was not used for the southern slope of the Tatra Mts.

This paper presents the first lichenometric curve of Rhizocarpon geographicum for the southern slope of the Tatra Mountains located entirely in the territory of Slovakia, developed as a result of several years of research in this area.

\section{Study area}

The study covered the southern slope of the Tatra Mountain, located in the Velická Valley, the Velká Studena Valley and the Skalnatá Valley (Fig. 1). It is an area formed of granite and granodiorites (Piotrowska et al., 2015), with an alpine relief (Lukniš, 1973), located within the climate zones ranging from subalpine to subnival (Hess 1965, 1974). The mean annual temperature range from $3.6^{\circ} \mathrm{C}$ at Štrbské Pleso $\left(1,360 \mathrm{~m}\right.$ a.s.l.) to $2.7^{\circ} \mathrm{C}$ at Skalnaté Pleso (1,763 m a.s.l.) and mean annual precipitation from $968 \mathrm{~mm}$ at Štrbské Pleso $(1,360 \mathrm{~m}$ a.s.l.) to $1,421 \mathrm{~mm}$ at Skalnaté Pleso (1,763 m a.s.I.) (Hlavatá, Škvarenina, \& Čepčeková, 2011; Bičárová \& Holko, 2019). The research was conducted on objects whose location is marked in Figure 1. 

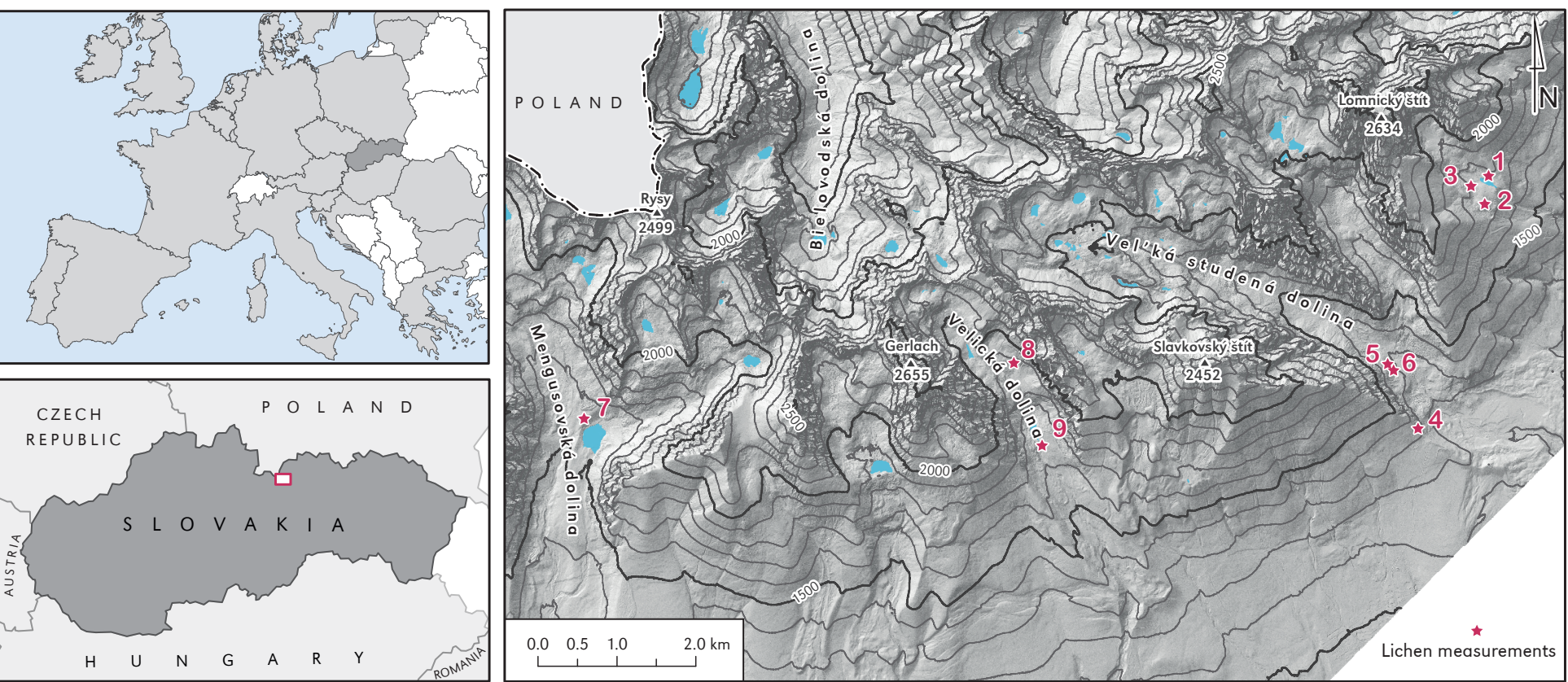

Figure 1. Location of study area. Map with measurement points: 1 - Vikend chata, 2 - Meteorological station (Skalnatá dolina), 3 -Skalnatá chata, 4 - Bilíkova chata, 5 - Rainerova chata, 6 - Chata Kamzík, 7 -Popradské pleso, 8 - Kvetnica, 10 - Blásyho chata. Hillshade DEM is based on aerial laser scanning data; ALS product

Source: ÚGKK SR. 


\section{Methods}

The measurements were carried out on Rhizocarpon geographicum lichens growing on the surface of granitoid boulders. The study was carried out in 2018 and 2019 on 50 objects, of which only 9 met the requirements and were used to construct the lichenometric curve. All the objects were located in concave forms, i.e. valley bottoms or on the lower parts of valley slopes. The valleys with the studied objects open out to the south or close to the southern direction. The altitude of the objects was determined using a Garmin Oregon GPS unit and topographic maps.

On each studied object the diameters of largest lichens were measured. The method of measuring of the largest lichen thallus diameter, i.e. the diameter of circle circumscribed around the lichen thalus (Fig. 2) was applied, as it had been in lichenometric research in the Tatra Mts. since the beginning. Measurements were made using a transparent ruler. Thalli with a small diameter (several millimetres) were measured with an accuracy of approx. $0.5 \mathrm{~mm}$ while thalli with a diameter of several tens of millimetres were measured with an accuracy of approx. $1 \mathrm{~mm}$. The accuracy of measurement was determined by the shape. The small thalli had a more regular shape, which allowed more accurate measurement. The shape of the large thalli was less regular, which made it difficult to measure them. The measurement error was between $2 \%$ and $10 \%$.

Based on the measurements, the average diameter of the five largest thalli (5LL) was calculated for each object. The only exception was the Blásyho chata measurement object where only 4 large thalli could be found, and those were used to calculate the average value. Knowing the age of the object, the age of the thallus with the calculated average diameter was determined. The lichen factor was then determined based on the ratio of the average diameter to the age.

\section{Results and discussion \\ Characteristics of the study objects and results of the measurements}

\section{Vikend chata}

This wooden house was built in 1936 for the workers constructing the cable car to the Lomnický štit peak (Konieczniak, 2010) and is situated at an altitude of $1,760 \mathrm{~m}$ a.s.l. The study was carried out on sites of rock surfaces exposed from under the soil cover when the ground was being levelled in preparation for construction

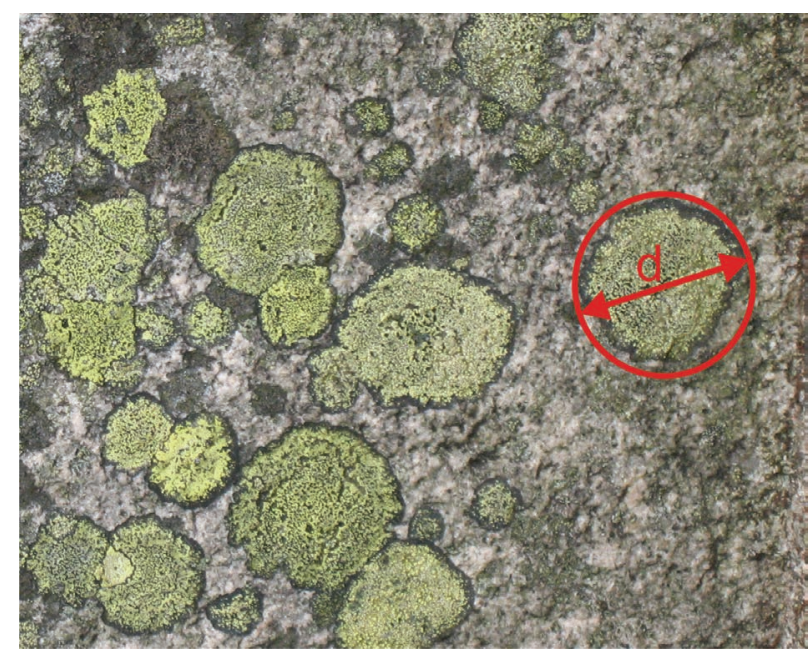

Figure 2. Measurement of the largest thallus diameter using the circumscribed circle method 
of the chalet. Some of the boulders uncovered at that time were not overgrown with vegetation so some thalli were preserved on them, and those were used to create the lichenometric curve. The largest thalli had a diameter of approx. $31.5 \mathrm{~mm}$ (Tab. 1).

2. Meteorological station (Skalnatá dolina) A brick building at an altitude of $1,778 \mathrm{~m}$ a.s.l. in which there is a meteorological and astronomical observatory. The construction was completed in 1943. Prior to the construction that was commenced in 1939, the surface was levelled and railway tracks were laid to transport building materials and equipment from the railway station at Skalnaté pleso (Skalnaté Lake) to the site. The thalli were measured on boulders exposed during the construction of the railway tracks. Their maximum diameter was approx. $30 \mathrm{~mm}$ (Tab. 1).

3. Skalnatá chata

The shelter is situated at an altitude of $1,725 \mathrm{~m}$ a.s.l., it was the first shelter for tourists climbing Lomnický štit. Initially, it was a rock shelter, which was repeatedly extended in subsequent periods (Konieczniak, 2010). In 1877, during extension work, some large boulders were moved and are now located on the western side of the chalet. The rock surfaced uncovered at that time became overgrown with thalli, the largest of which reached a diameter of approx. $50 \mathrm{~mm}$ (Tab. 1).

4. Bilíkova chata

The shelter was built in 1934 and then extended in 1935-1936 (Konieczniak, 2010). Unfortunately, the chalet itself, like other facilities of this type, is not suitable for lichenometric dating due to the lack of a surface with thalli meeting the requirements of this dating method. The thalli were measured just outside the chalet, on boulders lying at an altitude of $1,255 \mathrm{~m}$ a.s.l., the surface of which was unearthed in 1936 during restoration of the tourist route. The diameter of the largest thalli was approx. $32 \mathrm{~mm}$. It is the lowest-lying of all the objects based on which the lichenometric curve was created (Tab. 1).

\section{Rainerova chata}

One of the oldest shelters and at the same time the smallest one; it was built in 1865 at an altitude of $1,305 \mathrm{~m}$ a.s.l. (Konieczniak, 2010). Thalli were measured on some boulders marking the path built in 1997 and leading to the chalet. Their maximum diameters ranged from 9 to $10 \mathrm{~mm}$ (Tab. 1).

\section{Chata Kamzík}

A large shelter right next to the Rainerova chata shelter, built in 1884 and demolished in 1980. The foundations of this

Table 1. Description of measurementpoints

\begin{tabular}{|c|c|c|c|c|c|c|}
\hline Number & Measurement points & $\begin{array}{l}\text { Altitude } \\
\text { [m a.s.l.] }\end{array}$ & $\begin{array}{c}\text { Year } \\
\text { of formation/ } \\
\text { construction }\end{array}$ & $\begin{array}{c}\text { Age } \\
\text { [years] }\end{array}$ & $\begin{array}{l}\text { Mean max. } \\
\text { diameter (5LL) } \\
{[\mathrm{mm}]}\end{array}$ & $\begin{array}{l}\text { Lichen factor } \\
{[\mathrm{mm} / 100 \text { years] }}\end{array}$ \\
\hline 1 & Chata Vikend & 1760 & 1936 & 83 & 31.5 & 37.8 \\
\hline 2 & $\begin{array}{l}\text { Meteorological station } \\
\text { (Skalnatá dolina) }\end{array}$ & 1778 & 1939 & 80 & 30.0 & 37.5 \\
\hline 3 & Skalnatá chata & 1725 & 1877 & 142 & 50.0 & 35.0 \\
\hline 4 & Bilíkova chata & 1255 & 1946 & 73 & 32.0 & 43.8 \\
\hline 5 & Rainerova chata & 1305 & 1997 & 22 & 9.5 & 42.7 \\
\hline 6 & Chata Kamzík & 1303 & 2007 & 12 & 5.0 & 41.7 \\
\hline 7 & Popradské Pleso & 1520 & 1922 & 89 & 34.5 & 38.6 \\
\hline 8 & Kvetnica & 1900 & 2002 & 16 & 5.5 & 34.4 \\
\hline 9 & Blásyho chata & 1670 & 1929 & 90 & 34.0 & 37.7 \\
\hline
\end{tabular}


shelter were dismantled and taken away only in 2006 (Konieczniak, 2010). However, some of the boulders were left around the chalet, and it was on their surfaces, exposed during the demolition, that thalli were measured. The maximum diameter of these thalli was approx. $5 \mathrm{~mm}$ (Tab. 1).

7. Popradské pleso

The first shelter was built there in 1879 . It was repeatedly extended and rebuilt e.g. in 1922, and is the mountain hotel now (Konieczniak, 2010). Thalli were measured on boulders situated just by the retaining wall surrounding the square in front of the chalet. Their maximum diameter ranged between 34 and $35 \mathrm{~mm}$ (Tab. 1).

8. Kvetnica

Debris flows with known age are some of the best objects for measuring purposes. The studied debris flow track is located in Velická dolina (Velická Valley) at a place called Kvetnica, at an altitude of approx. 1,900 m a.s.l. (Kapusta, 2015). The levée of debris flow from 2002 were identified. The diameters of the largest thalli on this levée were in the range of 5-6 mm. The larger thalli also occur in several parts of this debris flow tracks, on landforms of older debris flows, but of unknown date of formation (Tab. 1).

\section{Blásyho chata}

This shelter was built in 1871-1872 at Velické pleso lake at an altitude of 1,670 m a.s.l. Unfortunately it was destroyed by a snow avalanche in 1874, and in later years demolished (Konieczniak, 2010). At present, only some fragments of the boulders from which it was built are left. The diameters of the largest thalli were in the range of 33-35 $\mathrm{mm}$ (Tab. 1).

\section{Lichen curves for southern slopes of the Tatra Mountains}

The first measurements of thalli on objects with a known date of origin based on which A. Kotarba determined the first lichenometric curves for the Tatra Mts. showed that the lichen factor changes with altitude. As the altitude increases, the thallus growth decreases. Therefore, A. Kotarba (1988) developed two lichenometric curves for the northern slope of the Tatra Mts., one for the very cool zone and one for the temperate cold zone (Fig. 3).

The use of two lichenometric curves increases the accuracy of the measurement, but creates a problem when measuring objects with high vertical extension, e.g. debris flows, because two growth curves cannot be used for one object. For this reason,

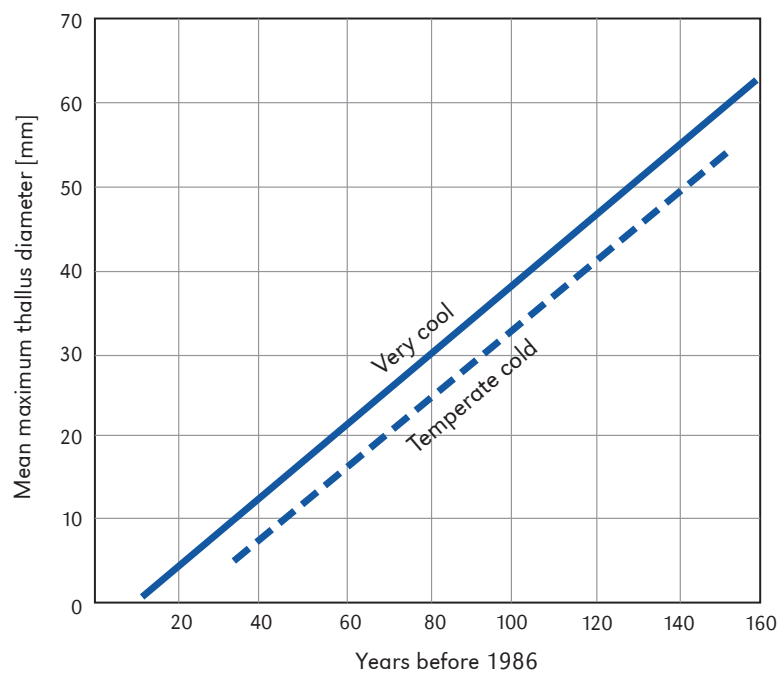

Figure 3. Lichenometric curves for the temperate cold and very cool climatic belts (Kotarba, 1988) 
when developing the lichenometric curve for the southern slope of the Tatra Mts., it was decided to determine two curves.

The first curve was created in the traditional way, i.e. based on thalli measured on objects located at different altitudes, from approx. $1,250 \mathrm{~m}$ to approx. $1,900 \mathrm{~m}$ a.s.l. (Fig. 4). It is described by the equation:

$$
y=-0.0007 x^{2}+0.4618 x-0.7383
$$

where: $R^{2}=0.9928$.

As can be seen in Figure 4, not all average diameters of the largest thalli of a particular object lie exactly on the lichenometric curve. This is not only due to the accuracy of the measurements of the thalli but also to the altitude and the associated different rate of thallus growth. When determining the lichenometric curve, the highest accuracy is achieved if objects of different ages and at different altitudes available. Unfortunately, this is rarely the case. The course of the upper part of lichenometric curve for the southern slope of the Tatra Mts. (Fig. 4) was strongly affected by the thalli measured on boulders at the Skalnata chata station (the highest point on the lichenometric curve), i.e. located on one object only. In order to increase the accuracy of the lichenometric curve, there should be more such objects, as is the case in its central and lower course. Unfortunately, it was not possible to find more objects older than 100 years and with thalli that would meet the requirements of this dating method. Therefore, the rate of lichens growth, determined by course of the lichenometric curve shown in Figure 4, may slightly differ from the actual rate of their growth at individual heights and age ranges.

When using this curve for lichenometric dating, it should also be borne in mind that all objects used for its construction were located in the bottom of valleys or on the lower parts of their slopes. In the case of dating objects situated on convex landforms (ridges or peaks) characterised by climatic conditions different from valley bottoms, the growth rate of thallus on such landforms may differ from the growth rate determined from the lichenometric curve (Kędzia \& Parzóch, 2016). Thus, the accuracy of dating with this method will be reduced. The same applies to objects located significantly below or above the altitudinal range for which the lichenometric curve was constructed.

When lichenometric dating is used for objects at low altitude (below the range for which the curve was constructed), the effect of air pollution on thallus growth must also be taken into account (Haffner, Lomsky, Hynek, Hallgren, Batic, \& Pfanz, 2001).

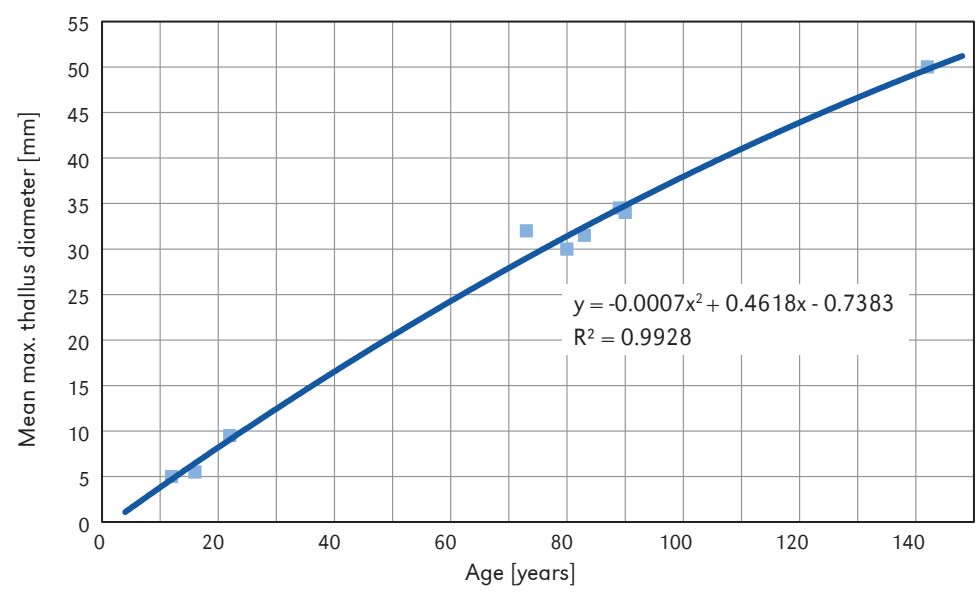

Figure 4. Lichenometric curve for the southern slope of the Tatra Mts. constructed based on the average of the largest thallus diameters 
It was not possible to find Rhizocarpon geographicum thalli below an altitude of approx. 1,000 m a.s.l. when the first lichenometric curves for the Polish part of the Tatra Mts. was elaborated. The reason was the high air pollution that persisted in the inversion layer over the town of Zakopane (Kotarba, oral information). A similar situation may occur in the Slovak part of the Tatra Mts. where there are numerous localities also at the foot of the mountains.

Figure 5 presents the lichenometric curve for the northern slope of the Tatra Mts. developed by S. Kędzia (2015) and the curve for their southern slope. A comparison of both curves demonstrates that the rate of growth of Rhizocarpon geographicum thalli on both sides of the Tatra Mts. is very similar. Unfortunately, it cannot be clearly stated whether the differences visible in the course of the curves, especially their upper parts, are the result of inaccuracy of measurements or climatic differentiation. In order to do so, it would be necessary to carry out detailed research aimed at finding objects formed in the same period on both sides of the Tatra Mts., situated at the same altitude and in similar terrain forms.

An important problem in lichenometric dating, which has been demonstrated in many studies, is the decrease in the rate of thallus growth, resulting from the changes in climatic conditions with increasing altitude (Beschel, 1961; Coxson \& Kershaw, 1983; Benedict, 1990, 1991; Armstrong, 2002, 2005, 2006, 2013, 2015, 2016; Solomina \& Calkin, 2003; Armstrong \& Bradwell, 2010b, 2015; Hansen, 2010; Trenbirth \& Matthews, 2010). Therefore, another curve was constructed based on the collected data, showing the variability of the lichen factor depending on the altitude (Fig. 6). It is described by the equation:

$$
\begin{aligned}
& y=-1.9485 x^{2}+83.36 x-1,297.3 \\
& \text { where } R^{2}=0.8975
\end{aligned}
$$

With this curve, the error resulting from using the same value of lichen factor for objects located at different altitude can be avoided. Consequently, the accuracy of the lichenometric dating is increased. Unfortunately, even this curve has its disadvantages. As the research to date has shown, the growth rate of thalli is related to their age (e.g. Bradwell \& Armstrong, 2007; Bradwell, 2010). For thalli that reached a diameter of approx. $40 \mathrm{~mm}$, the growth rate decreases. In the case of the curve in question, it was only on one object that the average diameter of the largest 5 thalli exceeded $40 \mathrm{~mm}$.

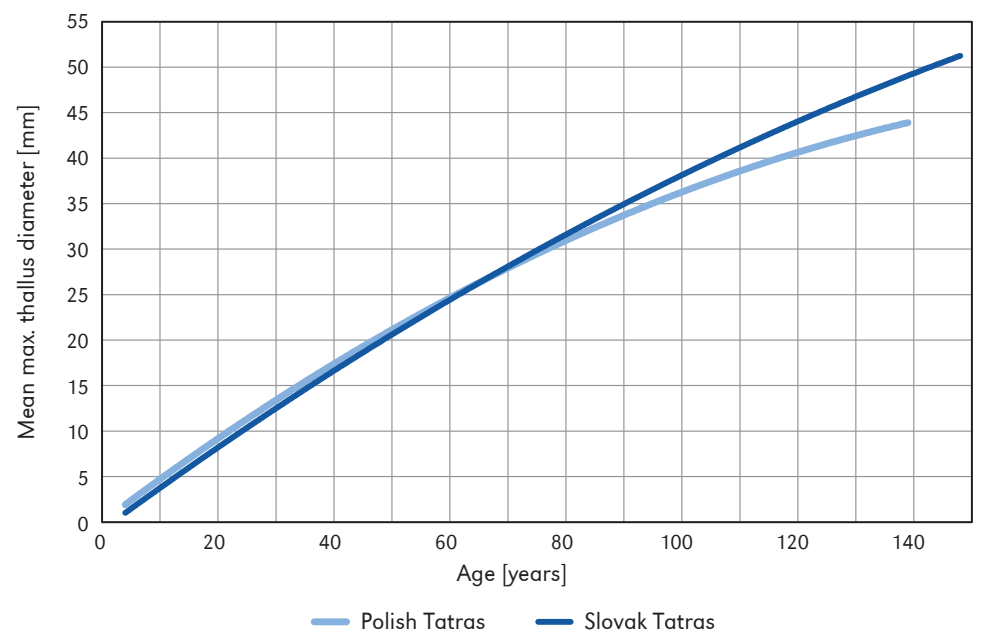

Figure 5. Lichenometric curve for the northern and southern slopes of the Tatra Mts. based on the average of the largest thallus diameters 
The differences in matching the mean values of the largest thallus measured on individual objects to the lichenometric curve at Figure 6 result from the accuracy of the thallus measurement. Small thalli with a diameter of e.g. $5 \mathrm{~mm}$ were measured with an accuracy of approx. $0.5 \mathrm{~mm}$, which gives an error of $10 \%$. On the other hand, large thalli, e.g. with a diameter of $50 \mathrm{~mm}$, were measured with a slightly greater inaccuracy of approx. $1 \mathrm{~mm}$, which is only $2 \%$ error regarding their diameter. The conclusion is the younger the thalli were measured, the greater error in determining the lichen factor were.

When comparing the lichenometric curve for the southern slope of the Tatra Mts with the curves developed for different parts of the Alps, it can be concluded that in terms of the thallus growth rate, the differences between the Tatra Mts. and some parts of the Alps are rather small. Lichen factor of approx. $43 \mathrm{~mm}$ was determined for the southern flanks of the Mont Blanc massif (Orombelli \& Porter, 1983). P. Pech et al. (2003) developed a curve for the Massif des Ecrins (French Alps) with a lichen factor of approx. $30 \mathrm{~mm}$, using a large number of measuring points situated well above 2,000 m a.s.I., while H. Blijenberg (1998), who also carried out research in the French Alps determined a lichen factor of approx. $38 \mathrm{~mm}$. M. Czempiński and M. Dąbski (2017) obtained a curve with a lichen factor of approx. $28 \mathrm{~mm}$ in Ötztal Alps at an altitude of approx. 2,000 m a.s.l. O. Sass (2010), on the other hand, determined a curve with a lichen factor of approx. $34 \mathrm{~mm}$ for the Stubai Alps (Austrian Alps). Also in the Austrian Alps, S. Winkler and R.A. Shakesby (1995) obtained an even greater lichen factor of approx. $38 \mathrm{~mm}$. However the above demonstrates not only similarities in the thalus growth rates, but also the relatively great local variability of these rates among particular parts of Alps.

\section{Conclusions}

The lichenometric curve developed for the southern slope of the Tatra Mts. is applicable for lichenometric dating in the altitude range from 1,250 to $1,900 \mathrm{~m}$ a.s.l. When dating objects outside this range, reduced dating accuracy must be taken into account. Lichen factor decreases with altitude. At an altitude of $1,250 \mathrm{~m}$ a.s.l. it is almost $44 \mathrm{~mm} / 100$ years, while at $1,900 \mathrm{~m}$ a.s.l. it is approx. $34.5 \mathrm{~mm} / 100$ years. Despite the climatic differences between the southern and northern slopes of the Tatra Mts., the growth rate of Rhizocarpon geographicum thallus on both sides of the Tatra Mts. is almost equal. Slight differences occur at higher altitudes.

All of the thalli used to determine the lichenometric curve grew on rock surfaces

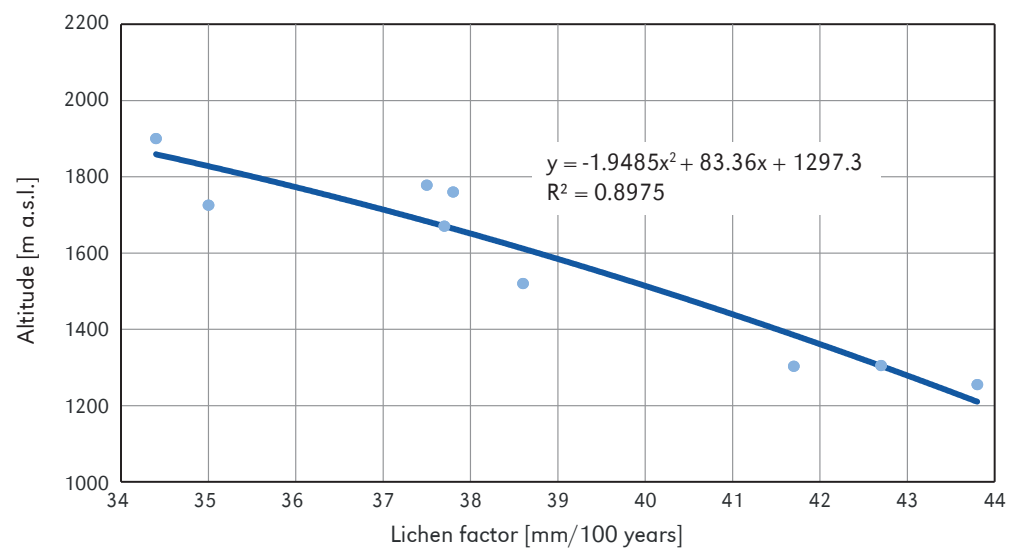

Figure 6. Lichenometric curve for the southern slope of the Tatra Mts. determined based on the lichen factor 
of granitoids; therefore, the curve can only be used to date objects built of granitoids. There is a need for further research to provide new data to refine the developed lichenometric curves, and to determine the thallus growth rate on the other types of rocks.

\section{Acknowledgements}

The authors would like to thank Prof. Adam Kotarba and Prof. Zofia Raczkowska for their comments in the course of writing this paper as well as Dr Slavomir Celer and MSc Alicja Kołodziejczyk for their help in field research. The research was conducted under projects of NAWA no. PPN/BIL/2018/00050/ IJ/00001 and APVVV SK-PL-18-0036.

Editors' note:

Unless otherwise stated, the sources of tables and figures are the authors', on the basis of their own research.

\section{References}

Armstrong, R.A. (1976). Studies on the growth rate of lichens. In D.H. Brown, D.L. Hawksworth, R.H. Bailey (Eds.), Progress and problems in lichenology (pp. 309-322). London: Academic.

Armstrong, R.A. (1978). The colonization of a slate rock surface by a lichen. New Phytologist, 81(1), 85-88. https://doi.org/10.1111/j.1469-8137.1978.tb01606.x

Armstrong, R.A. (1981). Field experiments on the dispersal, establishment and colonization of lichens on a slate rock surface. Environmental and Experimental Botany, 21, 116-120. https://doi.org/10.1016/0098-8472(81)90016-2

Armstrong, R.A. (1983). Growth curve of the lichen Rhizocarpon geographicum. New Phytologist, 94 , 619- 622. https://doi.org/10.1111/j.1469-8137.1983.tb04870.x

Armstrong, R.A. (2002). The effect of rock surface aspect on growth, size structure and competition in the lichen Rhizocarpon geographicum. Environmental and Experimental Botany, 48, 187-194. https://doi.org/10.1016/S0098-8472(02)00040-0

Armstrong, R.A. (2006). Seasonal growth of the crustose lichen Rhizocarpon geographicum (L.) DC. in South Gwynedd, Wales. Symbiosis, 41, 97-102. Retrieved from https://publications.aston.ac.uk/id/eprint/38468/1/RG_Seasonal_growth.pdf

Armstrong, R.A. (2013). Development of areolae and growth of the peripheral prothallus in the crustose lichen Rhizocarpon geographicum: An image analysis study. Symbiosis, 60, 7-15. https://doi.org/10.1007/s13199-013-0234-2

Armstrong, R.A. (2015). The influence of environmental factors on the growth of lichens in the field. In D.K.Upreti, P.K. Divakar, V. Shukla, R. Bajpal (Eds.), Recent advances in Lichenology. India (pp. 1-18). Springer International Publishing. https://doi.org/10.1007/978-81-322-2181-4_1

Armstrong, R.A. (2016). Invited review: Lichenometric dating (lichenometry) and the biology of the lichen genus Rhizocarpon: Challenges and future directions. Geografiska Annaler: Series A, Pysical Geography, 98, 183-206. https://doi.org/10.1111/geoa.12130

Armstrong, R.A., Bradwell, T. (2001). Variation in thallus width and the growth of the lichen Rhizocarpon geographicum (L.) DC. Symbiosis, 30, 317-328. Retrieved from https://dalspace.library.dal.ca/bitstream/handle/10222/77871/VOLUME\%2030-NUMBER\%204-2001-PAGE\%20317.pdf?sequence=1

Armstrong, R.A., Bradwell, T. (2010a). The use of lichen growth rings in lichenometry: Some preliminary findings. Geografiska Annaler: Series A, Physical Geography, 92, 141-147.

https://doi.org/10.1111/j.1468-0459.2010.00383.x 
Armstrong, R.A., Bradwell, T. (2010b). Growth of crustose lichens: a review. Geografiska Annaler: Series A, Physical Geography, 92, 3-17. https://doi.org/10.1111/j.1468-0459.2010.00374.x

Armstrong, R.A., Bradwell, T. (2015). Growth rings in crustose lichens: Comparison with directly measured growth rates and implications for lichenometry. Quaternary Geochronology, 28, 88-95. https://doi.org/10.1016/j.quageo.2015.04.003

Benedict, J.B. (1967). Recent glacial history of an alpine area in the Colorado Front Range, USA. I. Establishing a lichen growth curve. Journal of Glaciology, 6, 817-832. https://doi.org/10.3189/s0022143000020128

Benedict, J.B. (1990). Experiments on lichen growth. I. Seasonal patterns and environmental controls. Arctic and A/pine Research, 22, 244-254. https://doi.org/10.1080/00040851.1990.12002788

Benedict, J.B. (1991). Experiments on lichen growth II. Effects of a seasonal snow cover. Arctic and Alpine Research, 23(2), 189-199. https://doi.org/10.1080/00040851.1991.12002836

Benedict, J.B. (2008). Experiments on lichen growth. III. The shape of the age-size curve. Arctic, Antarctic and Alpine Research, 40, 15-26. https://doi.org/10.1657/1523-0430(06-030)[benedict]2.0.co;2

Benedict, J.B. (2009). A review of lichenometric dating and its applications to archaeology. American Antiquity, 74(1), 143-172. https://doi.org/10.2307/25470542

Beschel, R.E. (1950). Flechten als Altersmaßstab rezenter Moränen. Zeitschrift für Gletscherkunde und Glazialgeologie, 1(2), 152-161.

Beschel, R.E. (1957). Lichenometrieim Gletschervorfeld. Jahrbuch des Vereins zum Schutze Alpenpflanzen und Alpentiere, 22, 164-185.

Beschel, R.E. (1961). Dating rock surfaces by growth and its application to glaciology and physiography (lichenometry). Geology of The Arctic: Proceedings of the first International Symposium on Arctic Geology.

Beschel, R.E. (1973). Lichens as measure of the age of recent moraines. Arctic and Alpine Research, 5(4), 303-309. https://doi.org/10.1080/00040851.1973.12003739

Blijenberg, H. (1998). Rolling stones. Triggering and frequency of hillslope debris flows in the Bachelard Valley, southern French Alps. Utrecht: Universitet Utrech, Faculteit Ruimtelijke Wetenschappen.

Bičárová, S., Holko, L. (2019). Meterorologické observatórium Skalnaté Pleso. Geophysicala Institute of SAS. Retrieved from http://gpi.savba.sk/GPIweb/ofa/index.php/sk/observatoria/skalnate-pleso/ item/304-meteorologicke-observatorium-skalnate-pleso

Birkenmajer, K. (1980). Lichenometric dating of glacier retreat at Admiralty Bay, King George. Island (South Shetland Islands, West Antarctica). Bulletin de l'Académie Polonaise de Sciences, Série des Sciences de la Terre, 27, 77-85.

Birkenmajer, K. (1981). Lichenometric dating of raised marine beaches at Admiralty Bay, King George Island (South Shetland Islands, West Antarctica). Bulletin de l'Académie Polonaise des Sciences, Série des Sciences de la Terre, 27, 119-127.

Birkenmajer, K. (1982). The Penguin Island volcano, South Shetland Islands (Antarctica): Its structure and succession. Studia Geologica Polonica, 74, 155-173.

Birkenmajer, K. (1991). Lichenometric dating of a mid-19th century lava eruption on Deception Island (West Antarctica). Bulletin of the Polish Academy of Sciences. Earth Sciences, 39, 467-475.

Bradwell, T. (2001). A new lichenometric dating curve for southeast Iceland. Geografiska Annaler: Series A, Physical Geography, 83(3), 91-101. https://doi.org/10.1111/j.0435-3676.2001.00146.x

Bradwell, T. (2009). Lichenometric dating: A commentary, in the light of some recent statistical studies. Geografiska Annaler: Series A, Physical Geography, 91(2), 61-69. https://doi.org/10.1111/j.1468-0459.2009.00354.x

Bradwell, T. (2010). Studies on the growth of Rhizocarpon geographicum in NW Scotland, and some implications for lichenometry. Geografiska Annaler: Series A, Physical Geography, 92(1), 41-52.

https://doi.org/10.1111/j.1468-0459.2010.00376.x 
Bradwell, T., Armstrong, R.A. (2007). Growth rates of Rhizocarpon geographicum lichens: A review with new data from Iceland. Journal of Quaternary Science, 22(8), 801-815. https://doi.org/10.1002/jqs

Coxson, D.S., Kershaw, W, (1983). The ecology of Rhizocarpon superficial II. The seasonal response of net photosynthesis and respiration to temperature, moist and light. Canadian Journal of Botany, 61(2), 3019-3030. https://doi.org/10.1139/b83-339

Czempiński, J., Dąbski, M. (2017). Lichenometry and Schmidt hammer tests in the Kaunertal glacier foreland (Ötztal Alps) during the AMADEE-15 Mars Mission Simulation. Miscellanea Geographica - Regional Studies on Development, 21(4), 190-196. https://doi.org/10.1515/mgrsd-2017-0027

Dabski, M. (2002). Dating of the Fláajökull moraine ridges, SE-Iceland; Comparison of the glaciological, cartographic and lichenometrical data. Jökull, 51, 17-24.

Dąbski, M. (2007). Lichenometryczna analiza rozkładu częstości jako metoda datowania moren lodowca Fláa (SE Islandia). Słupskie Prace Geograficzne, 4, 61-77.

Denton, G.H, Karlén, W. (1973). Lichenometry: its application to Holocene moraine studies in southern Alaska and Swedish Lapland. Arctic and Alpine Research, 5(4), 347-372.

Gqadek, B., Grabiec, M., Kędzia, S., Rączkowska, Z. (2016). Reflection of climate changes in the structure and morphodynamics of talus slopes (the Tatra Mountains, Poland). Geomorphology, 263, 39-49. https://doi.org/10.1016/j.geomorph.2016.03.024

Haffner, E., Lomsky, B., Hynek, V., Hallgren, J.E., Batic, F., Pfanz, H. (2001). Air pollution and lichen physiology. Physiological responses of different lichens in a transplant experiment following an SO2-gradient. Water, Air, \& Soil Pollution, 131(1-4), 185-201. https://doi.org/10.1023/a:1011907530430

Hansen, E.S. (2010). A review of lichen growth and applied lichenometry in southwest and southeast Greenland. Geografiska Annaler: Series A, Physical Geography, 92(1), 65-79. https://doi.org/10.1111/j.1468-0459.2010.00378.x

Hess, M. (1965). Piętra klimatyczne w polskich Karpatach Zachodnich. Zeszyty Naukowe UJ, Prace Geograficzne, 11, 1-267.

Hess, M. (1974). Piętra klimatyczne Tatr. Czasopismo Geograficzne, 45(1), 75-94.

Hlavatá, H., Škvarenina, J., Čepčeková, E. (2011). Bioclimatic and precipitation conditions in mountain and Alpine areas of Slovakia on example of High Tatras Mts. Životnéprostredie (Environment), 45(2), 64-70.

Innes, J.L. (1982). Lichenometric use of an aggregated Rhizocarpon species. Boreas, 11(1), 53-57. https://doi.org/10.1111/j.1502-3885.1982.tb00520.x

Innes, J.L. (1983). Size frequency distributions as a Lichenometric technique: An assessment. Arctic and Alpine Research, 15(3), 285-294. https://doi.org/10.2307/1550825

Innes, J.L. (1984). The optimal sample-size in Lichenometric studies. Arctic and Alpine Research, 16(2), 233-244. https://doi.org/10.2307/1551075

Innes, J.L. (1985a). A standard Rhizocarpon nomenclature for lichenometry. Boreas, 14(1), 83-85. https://doi.org/10.1111/j.1502-3885.1985.tb00890.x

Innes, J.L. (1985b). Lichenometry. Progress in Physical Geography, 9(2). https://doi.org/10.1177/030913338500900202

Innes, J.L. (1988). The use of lichens in dating. In M.Galun (Ed.), Handbook of Lichenology III (pp. 75-91). Florida: CRC Press, Boca Raton,.

Jochimsen, M. (1973). Does the size of lichen thalli really constitute a valid measure for dating glacial deposits? Arctic and Alpine Research, 54, 417-424.

Jonasson, C., Kot, M., Kotarba, A. (1991). Lichenometrical studies and dating of debris flow deposits in the High Tatra Mountains, Poland. Geografiska Annaler: Series A, Pysical Geography, 73(3), 141-146. https://doi.org/10.1080/04353676.1991.11880339 
Karlén, W. (1973). Holocene glacier and climatic variations, Kebnekaise Mountains, Swedish Lapland. Geografiska Annaler: Series A, Pysical Geography, 55(1), 29-63. https://doi.org/10.1080/04353676.1973.11879879

Karlén, W., Black, J.L. (2002). Estimates of lichen growth-rate in northen Sweden. Geografiska Annaler: Series A, Pysical Geography, 84(3-4), 225-232. https://doi.org/10.1111/j.0435-3676.2002.00177.x

Kędzia, S. (2010). The age of debris surfaces on the ŻółtaTurnia (the Polish Tatra Mts.). Geomorphologia Slovaca et Bohemica, 2, 29-38.

Kędzia, S. (2013a). New lichenometric curve for the Polish part of the Tatras. Przeglad Geograficzny, 85(1), 5-15. http://dx.doi.org/10.7163/PrzG.2013.1.4

Kędzia, S. (2013b). Problems and possibilities of lichenometric dating in Polish mountains. Geographia Polonica, 86(4), 363-374. http://dx.doi.org/10.7163/GPol.2013.29

Kędzia, S. 2014. Are there any active rock glaciers in the Tatra Mountains? Studia Geomorphologica Carpatho-Balcanica, 48, 5-16. https://doi.org/10.18172/cig.3350

Kędzia, S. (2015a). The occurrence of glaciers in the Polish Tatra Mountains during the Little Ice Age. Zeitschriftfür Geomorphologie, 59(2), 229-241. https://doi.org/10.1127/zfg/2014/0150

Kędzia, S. (2015b). Lichenometric curves for the Polish part of the Karkonosze and Tatra Mountains established with a new method. Zeitschriftfür Geomorphologie, 59(1), 103-118. https://doi.org/10.1127/0372-8854/2014/0141

Kędzia, S., Parzóch, K. (2016). Aktywność spływów gruzowych w polskiej części Karkonoszy w świetle badań lichenometrycznych. Przeglad Geograficzny, 88(3), 295-310. http://dx.doi.org/10.7163/PrzG.2016.3.0).

Konieczniak, J. (2010). Encyklopedia schronisk tatrzańskich. Kraków: Oficyna Wydawnicza Centralnego Ośrodka Turystyki Górskiej PTTK „Wierchy”.

Kotarba, A. (1988). Lichenometry and its application in geomorphological research. Wszechświat, 89(1), 13-15.

Kotarba, A. (1989).On the age of derbis slops in the Tatra Mountains. Studia Geomorphologica Carpatho-Balcanica, 23, 139-152.

Kotarba, A. (1991). On the ages and magnitude of debris flow in the Polish Tatra Mountains. Bulletin of the Polish Academy of Science, 39(2), 129-135.

Kotarba, A. (1997). Formation of high-mountain talus slopes related to debris-flow activity in the High Tatra Mountains. Permafrost and Periglacial Processes, 8, 191-204. https://doi.org/10.1002/(sici)1099-1530(199732)8:2<191::aid-ppp250>3.0.co;2-h

Kotarba, A. (2001). Lichenometryczne oznaczanie wieku form rzeźby wysokogórskiej. Prace Geograficzne IGIPZ PAN, 179, 197-208.

Kotarba, A., Pech, P. (2002). The recent evolution of talus slopes in the High Tatra Mountains (with the Pańszczyca Valley as example). Studia Geomorphologica Carpatho-Balcanica, 36, 69-76.

Lock, W.W., Andrews, J.T., Webber, P.J. (1979). A manual for lichenometry. Norwich: Geo Abstracts for the British Geomorphological Research Group.

Lukniš, M. (1973). Reliéf Vysokých Tatier a ich predpolia. Bratislava: Slovenská akadémia vied

Matthews, J.A. (1974). Families of lichenometric dating curves from the Storbreen gletschervorfeld, Jotunheimen, Norway. Norsk Geografisk Tidsskrift - Norwegian Journal of Geography, 28(4), 215-235. https://doi.org/10.1080/00291957408551968

Orombelli, G., Porter, S.C. (1983). Lichen growth curves for the southern flanks of the Mont Blanc Massif, western Italian Alps. Arctic and Alpine Research, 15, 193-200. https://doi.org/10.2307/1550921

Pech, P., Jomelli, V., Baumgart-Kotarba, M., Chardon, M., Jacob, N., Kędzia, S., Kotarba, A., Raczkowska, Z., Tsao, C. (2003). Alichenometric growth curve in the French Alps: Ailefroide and Venon valleys; Massif des Ecrins. Geodinamica Acta, 16, 187-193.

https://doi.org/10.1016/j.geoact.2003.07.001 
Piotrowska, K., Danel, W., Iwanov, A., Gaździcka, E., Rączkowski, W., Bezák, V., Magla, J., Polák, M., Kohút, M., Gross, P. (2015). Plate IV. 1. Geology. Map 1. 1:100000. In K. Dąrowska, M. Guzik (Eds.), Atlas Tatr: Przyroda nieożywiona. Zakopane: Tatrzański Park Narodowy.

Sass, O. (2010). Spatial and temporal patterns of talus activity - a lichenometric approach in the Stubaier Alps, Austria. Geografiska Annaler: Series A, Physical Geography, 92(3), 375-391. https://doi.org/10.1111/j.1468-0459.2010.00402.x

Sołomina, O., Calkin, P.E. (2003). Lichenometry as applied to moraines in Alaska, U.S.A., and Kamchatka, Russia. Arctic, Antarctic, and Alpine Research, 35(2), 129-143. https://doi.org/10.1657/1523-0430(2003)035[0129:LAATMI]2.0.CO;2

Sołomina, O., Ivanov, M.N., Bradwell, T. (2010). Lichenometric studies on moraines in the Polar Urals. Geografiska Annaler: Series A, Physical Geography, 92(1), 81-99. https://doi.org/10.1111/j.1468-0459.2010.00379.x.

Trenbirth, H.E., Matthews, J.A. (2010). Lichen growth rates on glacier forelands in southern Norway: preliminary results from a 25-year monitoring programme. Geografiska Annaler: Series A, Physical Geography, 92(1), 19-39. https://doi.org/10.1111/j.1468-0459.2010.00375.x

Ustrnul, Z., Walawender, E., Czekierda, D., Štastný, P., Lapin, M., Mikulová, K. (2015). Opady atmosferyczne i pokrywa śnieżna. In Atlas Tatr: Przyroda Nieożywiona. Zakopane: Tatrzański Park Narodowy.

Weber, P.J., Andrews, J.T. (1973). Lichenometry: A commentary. Arctic and Alpine Research, 5(4), 295-302. https://doi.org/10.1080/00040851.1973.12003738

Winkler, S., Shakesby, R.A. (1995). Anwendung von Lichenometrie und Schmidt-Hammer zurrelativen Altersdatierung präfrührezenter Moränen am Beispiel der Vorfelder von Guslar-, Mitterkar-, Rofenkar- und Vernagtferner (Ötztaler Alpen/ Österreich). Petermanns Geographische Mitteilungen, 139, 283-304. 